\title{
Victim Impact Statement Model in Criminal Justice System in Restorative Justice Perspective
}

\author{
Hervina Puspitosari ${ }^{1 *}$ and Bintara Sura Priambada ${ }^{2}$ \\ ${ }^{1}$ Faculty of Law, Universitas Surakarta, Indonesia \\ ${ }^{2}$ Faculty of Law, Universitas Surakarta, Indonesia
}

\begin{abstract}
Practice of restorative justice is the handling of criminal acts that are not only seen from the perspective of the law, but also related to moral, social, economic, religious and customary aspects. Local customs, as well as various other restorative considerations will deal with the perpetrators, victims, and stakeholders in the community, in collective problem solving, the purpose of which is to repair damage, restore the quality of relationships and facilitate the reintegration of the parties involved and related. This study uses research methods with a normative juridical research approach. Restorative Justice, namely the punishment imposed by the court is a punishment aimed at maximizing the condition of the victim as before the criminal incident befell the victim. The issue of justice and respect for human rights does not only apply to criminals but also victims of crime who must get a sense of justice so that the objective of the criminal justice system can be achieved with a sense of justice for the victims and perpetrators. It is very important to immediately make efforts to reform the criminal law that puts forward the substantial justice of victims and perpetrators.
\end{abstract}

\section{Introduction and Literary Review}

Crime is human behavior that violates norms (criminal law), harms, irritates, and raises victims, so it cannot be allowed. So that any form of crime must be prevented and overcome. Many people agree that although crime is not something that can be eradicated or abolished, it needs to be addressed and taken seriously [1]. Growth and progress in the development of the economic, socio-cultural, scientific and technological fields as well as the increasing flow of information have greatly affected the increase and form of crime that has taken place, which needs to be fully and continually mitigated.

To overcome the problem of crime, the efforts that can be done can be grouped into two aspects, namely before the occurrence of crime or preventive efforts and after a crime or repressive attempt. Efforts in tackling crime are a means as a reaction that can be given to criminals, in the form of criminal (penal) and non-criminal (nonpenal) facilities, which can be integrated with each other. If the criminal means is called to tackle crime, it means that the criminal law politics will be carried out, namely holding elections to achieve the results

* Corresponding author: hervina@unsa.ac.id 
of criminal legislation that are appropriate to the situation and situation at a time and for the future.

According to GP Hoefnagels, efforts to overcome crime are carried out by: a) Application of criminal law (criminal law application); b) Criminal prevention (prevention without punishment); c) Influencing the views of society through crime and punishment through mass media (influencing views of society on crime and punishment / mass media) [2].

Thus, efforts to overcome crime can be divided into two parts, namely through the path of "(Criminal law) and through the" non-penal "route (not / outside of criminal law). In the division of GP Hoefnagels above, the efforts in points (b) and (c) can be included in the nonpenal effort group.

Barnest and Teeters show several ways to overcome crime, namely: a) Realizing that there will be needs to develop social impulses or social pressures and economic pressures that can influence a person's behavior toward evil deeds; b) Focusing on individuals who show criminal or social potentiality, even though the potentiality is caused by biological and psychological disturbances or lack of good socioeconomic opportunities so that it can be a harmonious unity. From Barnest and the Teeters opinion above shows that crime we can overcome if the economic situation or social environment that affects a person towards criminal behavior can be restored in good condition. In other words, the improvement of the economic situation is absolutely necessary. While biological factors, psychological, are only secondary factors [3].

Judging from the definition of a criminal act that violates criminal regulations, is threatened with punishment by law and carried out by a person with guilt, which person must be accountable, and the police should also be able to maintain and implement the rules that have been established, if we reviewing it further than this understanding there are several elements of offense, namely: a) The existence of an element of action; b) There are elements of violation of criminal regulations; c) The existence of an element threatened with a threat of punishment; d) Done with mistakes.

The element of offense which is an element of the nature of unlawful behavior is an act, because only that action is only followed by the elements of the object, which can be divided into several parts including: a) The act has been formulated by law; b) The act is illegal; c) Done with mistakes; d) The act is threatened by criminal action.

Act is an act that is prohibited by the rule of law, prohibition is accompanied by threats, or sanctions in the form of a particular criminal for anyone who violates the prohibition. Determine when and in what cases those who have violated the prohibition can be charged or punished as threatened. Determine the way in which the imposition of a criminal is carried out if there is a person suspected of having violated the prohibition.

A person is said to have committed a crime if it meets the following elements: a) Criminal acts in the broadest sense of man (active and letting); b) Unlawful nature (both subjective and objective); c) Be accountable to someone; d) Threatened with crime [4].

In international forums, especially in the development of the United Nations congresses on "The Prevention of Crime and the Treatment of Offenders," the problem of prevention / overcoming crime is more seen in the context of global development / social policy. The crime prevention / prevention strategy according to the UN congresses is outlined as follows/ prevention of [2]: a) The basic strategy crime is to eliminate the factors that cause crime; b) Prevention of crime and criminal justice must be pursued with an integral / systemic policy (not simplistic and fragmanteir; c) Crimes that get the attention of the UN Congress to be tackled; one of them is cybercrime; d) It is necessary to improve and improve the quality of law enforcement officers; e) It is necessary to improve and improve the quality of institutions and organizational management / data management systems; f) Compilation of "Guidelines", "Basic Principles", "Rules", "Minimum Rules (SMR); g) Enhanced" international cooperation (international cooperation) and technical assistance (technical assistance) in 
order to strengthen " the rule of law "and" management of criminal justice system. "Criminal justice as a place for testing and enforcing human rights has a special characteristic, which consists of sub-systems which are independent institutions, but must work integrated in order to enforce the law in accordance with the expectations of the community from justice: The criminal justice process consists of stages ranging from investigations, investigations, arrests, detention, prosecutions, hearings at the trial, to the criminal process. The Criminal Justice System or criminal justice system has now become a term that shows the working mechanism in crime prevention using a systems approach [5].

Problems that occur with the criminal system include over capacity of detention centers and prisons which have an impact on criminal acts that occur in the detention and prison environment. Another problem is related to the interests and losses of victims with the system of prosecution of perpetrators.

The concept of a restorative justice approach is an approach that focuses more on the condition of creating justice and balance for the perpetrators of the crime and the victims themselves. The procedural and criminal justice mechanisms that focus on prosecution are converted into a process of dialogue and mediation to create an agreement on the settlement of criminal cases that are more just and balanced for the victims and perpetrators.

The concept of restorative justice has a meaning as justice that restores which includes recovery between victims and perpetrators. The victim can convey the loss suffered and the perpetrator is given the opportunity to redeem it, through a mechanism of compensation, peace, social work, and other agreements. From the aforementioned study, it is necessary to form a victim's statement of suffering to the panel of judges (victim impact statements) in the criminal justice system. So that victims can convey what they really want from the trial process aimed at seeking justice.

\section{Objective of the Study}

This article examines what is the model of victim impact statements in the criminal justice system in the perspective of restorative justice and what is the impact of victim impact statements in the criminal justice system in the perspective of restorative justice.

\section{Methodology}

Legal research is a process for finding legal rules, legal principles, and legal doctrines in order to answer the legal problems faced. This study uses a research method with a juridormative research approach.

\section{Discussion}

\subsection{The model victim impact statement in the criminal justice system in the perspective of restorative justice}

The original concept of restorative justice practices originated from the practice of peacekeeping used by Maori tribes, Native Americans. According to Hellen Kowie, restorative justice basically lies in the concept of a caring and exclusive community. When conflicts arise, restorative practices will deal with the perpetrators, victims, and stakeholders in the community, in collective problem solving, the aim of which is to repair damage, restore the quality of relationships and facilitate the reintegration of the parties involved and related. Contrary to the 'traditional punishment' approach to discipline, restorative justice practices place more emphasis on the perpetrators and victims so that the settlement does not stop at 
the punishment of the offender, but the attainment of maturity for the parties concerned to strengthen the quality of the relationship for a longer period of time.

Jeff Christian, an international correctional expert from Canada said that actually the restorative act has been practiced by many people for thousands of years before long before the formalistic state law as it is today, which was later called modern law. According to him, restorative justice is a handling of criminal acts that are not only seen from the perspective of the law, but also related to moral, social, economic, religious and local customs aspects, as well as various other considerations. Criminal concepts and theories continue to develop from traditional justice theories such as retributive justice to modern justice theory such as justice. It is not easy to provide a definition of restorative justice, because many variations of models and forms develop in their application. Therefore, many terminologies are used to describe the concept of restorative justice, such as communitarian justice, positive justice, relational justice, reparative justice, and community justice [6].

According to Muladi, restorative justice is a theory that emphasizes restoring losses caused or caused by criminal acts. Restoring this loss will be achieved by the existence of cooperative processes that include all interested parties. The restorative definition is just according to Muladi basically has the same thing with the definition formulated by the following Prison Fellowship International:"Restorative justice is a theory of justice that emphasizes reparation caused by criminal behavior. It is best accomplished when the parties meet cooperatively to decide how to do this. This can lead to transformation of people, relationships and communities [7].

In more detail Muladi states that restorative justice model has several characteristics, namely [8]:

a. Crime is formulated as a violation of another person and is recognized as a conflict;

b. Points of attention to solving problems of accountability and liability in the future;

c. Normative nature is built on the basis of dialogue and negotiation;

d. Restitution as a means of improving the parties, reconciliation and restoration as the main objectives;

e. Justice is formulated as rights relations, assessed on the basis of results;

f. Target attention to repairing social losses;

g. The community is a facilitator in the restorative process;

$\mathrm{h}$. The role of the victim and the perpetrator of the crime is recognized, both in the problem and the settlement of the rights and needs of the victim. Offenders are encouraged to be responsible;

i. The perpetrator's accountability is formulated as an impact on understanding the actions and to help decide the best;

j. Criminal acts are understood in the context of overall, moral, social and economic;

k. Stigma can be removed through restorative actions.

According to Muladi, victims are people who both individually and collectively have suffered losses, including physical or mental, emotional, economic or substantial damage to their fundamental rights, through acts or commissions that violate the criminal laws in each country, including abuse of power. The position of victims in the criminal justice system and in the practice of justice is relatively under-emphasized because the provisions of Indonesian law are still based on the protection of the offender oriented. In the environment of learning public policy formulation, there are a number of models. Thomas R Dye formulated complete models in the nine policy formulation models, namely:

a. Institutional Model (Institutional)

The institutional model formulation simply means that the task of making public policy is the task of the government. So whatever the government makes in any way is public policy. 
b. Process Model (Process)

In this model its followers accept the assumption that the public is an activity so that it has a process for it.

c. The Group Model (Group)

Policy-making model presupposes policy as a point of balance as the core point of balance. The idea is that interaction in groups produces balance and balance is the best.

d. Elite Model (Elite)

The elite theory model developed from the political theory of mass elites based on the assumption that in every society there must be two groups, namely the holder of power or mass.

e. Rational Model

This model puts forward the idea that public policy as a maximum social gain means that the government as a policy maker must choose policies that provide optimum benefits for the community.

f. The Incremental Model

This model sees that public policy is a variation or continuation of past policies.

g. Game Theory Model

Game theory models are very abstract and deductive in policy formulations.

h. Public Choice Model

This policy model views policy as a process of collective decision formulation of individuals who have an interest in the decision.

i. System Model.

In this approach three groups are known as input, process and output.

The restorative justice process is basically carried out through discretion and diversion as an attempt to transfer from the criminal justice process to the formal process to be resolved through deliberation. The role of victim impact statement is needed in the criminal justice system that applies restorative justice so that it is more on the priority of what is desired by the victim to fulfill substantial justice between victims and perpetrators so that not only prioritizing the system of imprisonment but there are alternatives to criminal prosecution such as the social work system, compensation more on prioritizing the restoration of relations between victims and perpetrators so that a sense of justice can be created as a legal objective to create justice and peace.

\subsection{The impact of victim impact statements in the criminal justice system in the perspective of restorative justice}

Muladi argued that, the justice system is a judicial network that is a material criminal law, formal criminal law is a criminal law. However, this institution must be seen in the social context. The nature of being too formal if it is based on only legal interests will bring disaster in the form of justice.

Muladi emphasized that "integrated criminal justice system" is a synchronization or opportunity that can be distinguished in: a) Structural synchronization (structural synchronization) is uniformity and harmony within the framework of the relationship between law enforcement agencies; b) Substance synchronization (substantial synchronization) is vertical and horizontal uniformity and harmony in relation to positive law; c) Cultural synchronization (cultural synchronization) is uniformity and harmony in living out views, comprehensive attitudes and philosophies underlie the course of the criminal justice system [9]. 
Not all crimes that occur in society are resolved through the criminal justice system because there are unreported crimes. Criminal justice will run if the crime is reported by the police, then prosecuted, and the court gives its verdict which in the end the crime that originally came from the community, the output is also returned to the community.

The importance of the role of criminal legislation in the criminal justice system, because the legislation gives power to policy makers and provides a legal basis for the policies applied. Legislative institutions participate in preparing policies and provide legal steps to formulate policies and implement predetermined policy programs. So, all are part of legal politics which essentially functions in three forms, namely the formation of law, law enforcement, and the exercise of authority and competence. According to Muladi, the purpose of the criminal justice system can be categorized as follows: a) Short-term objectives, if what is to be achieved is the resocialization and rehabilitation of the perpetrators of the crime; c) Medium-term goals, if what is to be achieved is broader namely crime control and prevention in the context of criminal politics (criminal policy); c) Long-term goals, if what is to be achieved is social welfare in the social political context.

The purpose of the criminal justice system above is in line with the opinion of $\mathrm{P}$. Hoefnagels concerning criminal law policy that consists of criminal law politics (criminal policy) policy of criminal law enforcement (law enforcement policy) and social policy that the ultimate goal is to realize social welfare [10]. The criminal justice system composes a number of people receiving criminal sanctions is coming into contact with the police [11].

Mardjono Reksodipoerto gave the opinion that the criminal justice system is a system in a society to overcome crime problems. So that the purpose of the criminal justice system is: a) Preventing people from being victims of crime; b) Resolve criminal cases that occur so that the community is satisfied that justice has been heard and the guilty is convicted; c) Strive so that those who have committed crimes will not cope again [11].

Joseph Godstein offers three concepts in law enforcement is [10] :

a. Total enforcement is the scope of criminal law enforcement as expected and formulated by the substantive law of crime, which cannot be realized because of the limited movement of law enforcement caused by restrictions strictly by criminal procedural law which covers the rules or procedures for arrest, search, detention, confiscation up to the preliminary examination stage or perhaps also the limitation by the material criminal law itself, which determines that a criminal act can only be prosecuted based on a complaint (klacht delict).

b. Full enforcement, here law enforcers are expected to uphold the law maximally. Law of Full enforcement is an unrealistic expectation because there are constraints in its implementation in the form of time constraints, personnel, funding investigative tools and so on that require discretion.

c. Actual enforcement, which is a concrete law enforcement as a result of total enforcement minus the area of no enforcement, results in full enforcement, and the last is reduced by the existence of discretion (decision not to enforcement) resulting in actual law enforcement.

As a result of a victim impact statement in the criminal justice system in a perspective, the restorative justice fulfillment of justice is more on the priority of the victim's will as an effort to recover from the loss of the victim due to the crime committed by the perpetrator. So that it takes efforts to reform the criminal law from the substance of the provisions of the sanctions that are in the Criminal Code and amendments to the Criminal Procedure Code. Victim Impact Statement is a written statement in the form of details about the impact of criminal acts committed against a person as a victim. Victim Impact Statement was given to the Judge who sentenced the defendant to assist in determining the verdict for the offender. Therefore, that if the impact of a criminal act is known by the court, then the court must consider the impact statement system in passing a verdict. The Victim Impact Statement can 
take the form of accurate details of personal injury, loss or damage suffered by a victim as a result of a criminal offense, both in the short and long term, which is a direct result of the criminal act. Details of emotional and psychological injuries can be included and related medical reports and medical expenses can be attached. Victim Impact Statement is written by the victim of the crime itself. However, in certain cases, it can be written by others, including family members if the victim is not enabled to write it himself.

\section{Conclusion}

The model victim impact statement in the criminal justice system is in the perspective of restorative justice. The restorative justice process is basically carried out through discretion and diversion as an attempt to transfer from the criminal justice process to the formal process to be resolved through deliberation. The role of victim impact statement is needed in the criminal justice system that applies restorative justice so that it is more on the priority of what is desired by the victim to fulfill substantial justice between victims and perpetrators so that not only prioritizing the system of imprisonment but there are alternatives to criminal prosecution such as the social work system, compensation more on prioritizing the restoration of relations between victims and perpetrators so that a sense of justice can be created as a legal objective to create justice and peace.

The impact of a victim impact statement in the criminal justice system in a perspective restorative justice is the fulfillment of more justice on the priority of the victim's will as an effort to recover from the loss of the victim due to the crime committed by the perpetrator. So that a criminal law reform effort is needed from the substance of the provisions of the sanctions contained in the Criminal Code and amendments to the Criminal Procedure Code. Victim Impact Statement is a written statement in the form of details about the impact of criminal acts committed against a person as a victim. Victim Impact Statement was given to the Judge who sentenced the defendant to assist in determining the verdict for the offender. Therefore, that if the impact of a criminal act is known by the court, then the court must consider the impact statement system in passing a verdict.

\section{References}

1. M. Rukmini, Aspek Hukum Pidana dan Kriminologi (Sebuah Bunga Rampai), (Alumni, Bandung, 2006)

2. B. N. Arief, Bunga Ramoai Kebijakan Hukum Pidana; (Pranada Media Group, Jakarta, 2016)

3. R. Atmasasmita, Kapita Selekta Kriminologi, (Armico, Bandung, 1993)

4. Moelyatno, Perbuatan Pidana dan Pertanggungjawaban Pidana, (Bintang Indonesia, Bandung, 1998)

5. R. Atmasasmita, Perbuatan Pidana dan Pertanggungjawaban Pidana, (Jakarta, Kencana, 2011)

6. E. A. Zulfa, Definisi Keadilan Restoratif, http://evacentre.blogspot.com/2009/11/definisi-keadilan-restoratif.html

7. Prison Fellowship International, What Is Restorative Justice, https://pfi.org/category/restorative-justice/

8. Setyo Utomo, Makalah Sistem Pemidanaan Dalam Hukum Pidana Yang Berbasis Restorative Justice, (BPHN, Jakarta, 2010), in October 21, 2010

9. Y. Anwar, Adang, Sistem Peradilan Pidana (Konsep, Komponen dan Pelsanaanya Dalam Penegakan Hukum di Indonesia), (Widya Padjadjaran, Bandung, 2009) 
10. E. Dewi, Firganefi, Sistem Peradilan Pidana Indonesia (Dinamika dan Perkembangan), (Graha Ilmu, Yogyakarta, 2014)

11. S. L. R. Anleu, Law And Social Change Second Edition, (Sage, Los Angeles, 2010) 